\title{
Successful Treatment of Sphenopalatine Ganglion Radiofrequency Thermocoagulation in Trigeminal Autonomic Cephalalgia
}

\author{
Trigeminal Otonomik Sefalji Olan Bir Olguda Sfenopalatin Ganglion Radyofrekans \\ Termokoagülasyon ile Başarılı Tedavi
}

\author{
(1) Esra Ertilav1, (1) Osman Nuri Aydın², (1) Ali Akyol ${ }^{1}$ \\ ${ }^{1}$ Aydin Adnan Menderes University Faculty of Medicine, Department of Neurology, Division of Algology, Aydin, Turkey \\ 2Aydin Adnan Menderes University, Department of Anesthesiology, Division of Algology, Aydin, Turkey
}

\begin{abstract}
Sphenopalatine neuralgia (SPN) is a clinical condition characterized by unilateral periorbital, trigeminal-maxillary pain, and ipsilateral autonomic symptoms caused by peripheral irritation of the SP ganglion. SPN was a previous term for trigeminal autonomic cephalalgias (TACs), especially for cluster headache, with its pain characteristics and autonomic findings. Etiology, pain duration, and treatment response provide distinctive features. Its clinical recognition is difficult; however, distinguishing it from other headache syndromes is important to prevent inappropriate treatment approaches. This case report aimed to raise awareness of the diagnosis, differential diagnosis, and management of TACs by presenting successful treatment results with thermal coagulation directed to the SP ganglion. Keywords: Sphenopalatine ganglion, cluster headache, trigeminal autonomic cephalalgia
\end{abstract}

Öz

Sfenopalatin nevralji (SPN), SP gangliyonunun periferik irritasyonundan kaynaklanan tek taraflı periorbital, trigeminal sinirin maksiller trasesinde ağrı ve ipsilateral otonomik semptomlarla karakterize klinik bir durumdur. SPN, etiyolojisi, ağrı süresi ve tedavi yanıtı ile ayırt edici özellikler sağlasa da ağrı karakteristiği ve otonomik bulguları ile özellikle küme baş ağrısı olmak üzere trigeminal otonom sefaljinin (TOS) önceki bir terimi olarak kabul edilmektedir. SPN'yi klinik olarak tanımak ve ayırmak zor olsa da, uygun olmayan tedavi yaklaşımlarını önlemek için TOS'den ayırt etmek önemlidir. Bu olgu sunumunda SP gangliyonuna yönelik termal koagülasyon ile başarılı tedavi sonuçları sunularak TOS kliniğine, ayırıcı tanı özelliklerine ve tedavi yönetimine dikkati çekmek amaçlanılmıştır.

Anahtar Kelimeler: Sfenopalatin ganglion, küme baş ağrısı, trigeminal otonomik sefalji

\section{Introduction}

Sphenopalatine neuralgia (SPN) was first described by Sluder in 1908 (1). SPN is a sharp, boring, and burning pain in the maxillary nerve sensory areas, such as the unilateral periorbital, nasal root, and hard palate, and occurs with ipsilateral autonomic symptoms. SPN was was accepted as a previous term of cluster headache $(\mathrm{CH})$ and not included in the International Classification of Headache Disorders (ICHD-II) classification (2). Due to insufficient literature data, clinical classification and definitive diagnostic criteria are yet to be established. Although it is considered as a previous term of trigeminal autonomic cephalalgias (TACs), the area in which the pain spreads, the duration and severity of pain, the pattern of attacks, the absence of periodicity, and most importantly the absence of oxygen and indomethacin responses are probable distinctive features from $\mathrm{CH}$ and other TACs. Diagnostic blockage for the SP ganglion used in differential diagnosis and treatment is effective in $\mathrm{CH}$, but lack of clustering properties and oxygen response is the main distinguishing factor. In addition, $\mathrm{CH}$ is associated with central causes, such as trigeminal caudal nucleus sensitization and hypothalamic activation, whereas SPN occurs with peripheral etiology. SPN is associated with sensitization of the pterygopalatine ganglion through peripheral fibers due to trauma, dental, nasal, and infectious reasons (3). The clinical symptoms regress when the underlying causes, such as concha hypertrophy, septum deviation, sinus infection, pulpitis, and residual tooth root

Address for Correspondence/Yazışma Adresi: Esra Erilav MD, Aydin Adnan Menderes University Faculty of Medicine, Department of Neurology, Division of Algology, Aydin, Turkey

Phone: +90 5301408950 E-mail: eertilav@gmail.com ORCID: orcid.org/0000-0002-4315-1031

Received/Geliș Tarihi: 17.03.2020 Accepted/Kabul Tarihi: 24.02.2021

${ }^{\circ}$ Copyright 2021 by Turkish Neurological Society

Turkish Journal of Neurology published by Galenos Publishing House. 
fracture are eliminated. Patients with primary etiology respond to the recurrent SP ganglion blocks, and SP ganglion radiofrequency thermocoagulation is an option for permanent pain control. This case report aimed to raise awareness of this very rare pain condition.

\section{Case Report}

A 76-year-old male patient presented with a sharp and perpendicular pain that started with a sudden electric shock spreading to the deep groom at the root of his right nose for 9 months. The pain occurred daily and lasted about half a day. Some days it recurred 3-4 times in a day. The pain from the root of the nose was accompanied by runny nose and tearing of the right eye. While eating, washing his face, and talking, his pain became more severe and on some nights he woke up due to pain. Brain magnetic resonance imaging was normal. The patient was diagnosed with trigeminal neuralgia, and carbamazepine was initiated. The patient's liver function tests were elevated, and he was referred to us for the interventional procedure for the Gasser ganglion.

The patient's current pain did not match the trigeminal neuralgia in terms of duration and localization. Autonomic symptoms accompanying pain led to the diagnosis of TAC, specifically SPN. He underwent a transnasal SP block with lidocaine. Waters X-ray and dental X-ray revealed dental fillings. The visual analog scale score (VAS) of the patient was 5 (VAS before the procedure: 8). SP ganglion radiofrequency thermocoagulation was applied at 80 degrees for 90 seconds (Figure 1). The patient reported no complaints except for slight tingling during his control visit one month later (VAS: 2). At 12 months follow-up VAS was 4 , and transnasal SP blockage was reapplied. Medical treatment was started with pregabalin at $150 \mathrm{mg} /$ day and continued with $300 \mathrm{mg} /$ day.

\section{Discussion}

The SP ganglion (pterygopalatine ganglion) is a large ganglion connected with many sensory and motor nerves and sympathetic and parasympathetic fibers. The outer periphery is connected through the nasal mucosa, located under the maxillary nerve on the middle turbinate pterygopalatine fossa. The SP ganglion receives sensory fibers from the maxillary nerve, motor fibers from the facial nerve, and sympathetic postganglionic efferent sympathetic fibers from the superior cervical ganglion. The ganglion has preganglionic parasympathetic fibers, which synapse with the trigeminal nerve and the nasal mucosa, soft palate, tonsils, uvula, lip and gums, teeth and neurons scattering to the pharynx, and vasodilator and secretory fibers of the postganglionic axons. The postganglionic parasympathetic fibers go to the lacrimal gland through a branch of the maxillary nerve and connect with a branch of the ophthalmic nerve (4).

The ganglion is associated with many autonomic and somatic sensory nerves; thus, it presents with atypical head and neck and facial pain that is clinically undifferentiated. Therefore, trigeminal neuralgia and TACs constitute the most involved group in the differential diagnosis.

SPN usually shows a pain pattern at the unilateral nasal root, hard palate, teeth, and trigeminal distribution, and spreading to the neck, lasting from 3 hours to 1 week and accompanied by autonomic symptoms. The pain spread in the head and neck, lasting for hours and days, and accompanied by autonomic symptoms distinguishes SPN from other neuralgias. SPN is a different entity, although it is particularly similar to TACs, especially $\mathrm{CH}$. SPN was a previous term for $\mathrm{CH}$; however, pain duration, severity, area of spread, response to oxygen treatment, and pathophysiology varies. The etiopathogenesis of $\mathrm{CH}$ is due to central causes, such as hypothalamic activation and trigeminocaudal nucleus sensitivity, whereas the SPN occurs due to peripheral sensitization of the SP ganglion (5).

Pain character, location, duration, persistence, and treatment response assist in the differential diagnosis; however, patients often experience delays in diagnosis and appropriate treatment. In pharmacological treatment, carbamazepine, oxcarbazepine, gabapentin, and pregabalin are used. Interventional methods come into question in case of side effects to medical treatment or in resistant cases. Treatment for structural lesions around the SP ganglion is recommended in cases with secondary etiology; however, diagnostic blocks are recommended in idiopathic cases (6). The SP ganglion radiofrequency thermocoagulation efficacy was reported in patients benefiting from diagnostic blocks (7). Therefore, in cases where SPN is suspected, response evaluation of the transnasal SP ganglion block may be considered. Otherwise, non-targeted approaches, such as invasive interventions to the trigeminal nerve, indomethacin response, temporomandibular

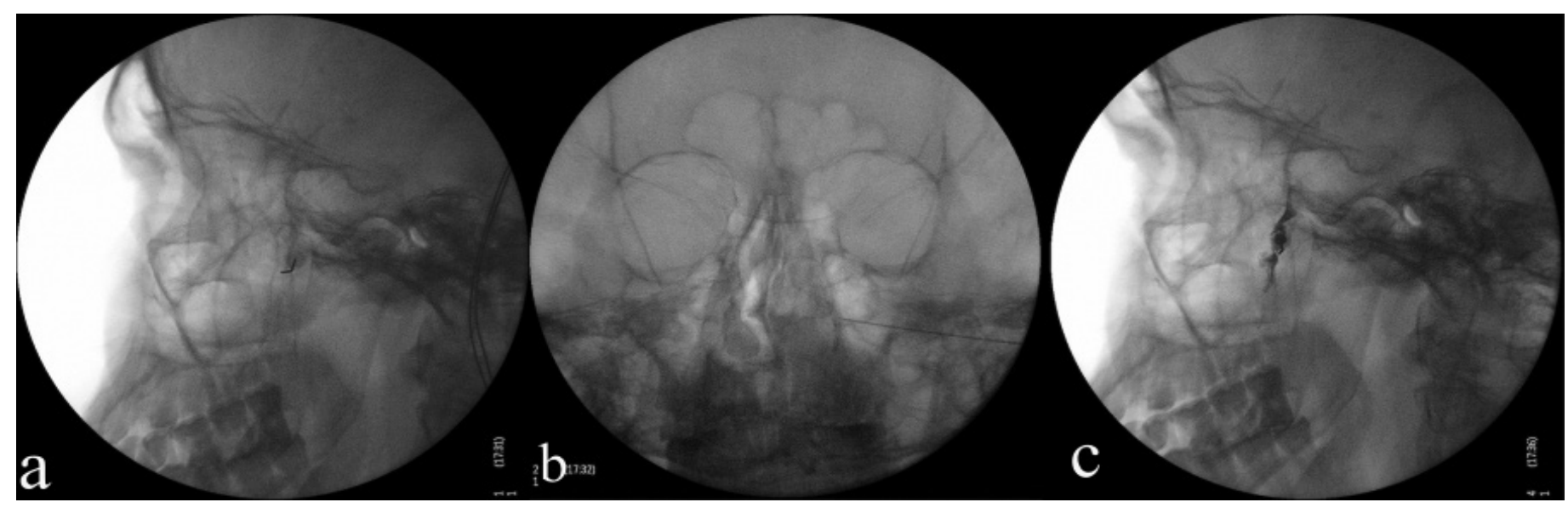

Figure 1. Fluoroscopic image of a needle in pterygopalatine fossa on lateral position (a), posterior-anterior position (b), and contrast spread to the pterygopalatine fossa after contrast injection (c) 
joint operations, and tooth extraction, are preferred in these patients.

SPN is not included in the ICHD-II classification and was a previous term of $\mathrm{CH}$ for many years. It is not included in the current ICHD, third edition 2018 either (8). However, SPN is debated as an independent and rare neuralgia entity. The classification and diagnostic criteria should be reviewed and added to the classification, not as a $\mathrm{CH}$ variant but as a separate entity $(3,5)$.

\section{Ethics}

Informed Consent: Informed consent was obtained from the patient.

Peer-review: Externally and internally peer-reviewed.

\section{Authorship Contributions}

Concept: E.E., O.N.A., Design: E.E., O.N.A., A.A., Data Collection or Processing: E.E., O.N.A., Analysis or Interpretation: E.E., O.N.A., A.A., Literature Search: E.E., O.N.A., Writing: E.E., O.N.A., A.A.

Conflict of Interest: The authors have not declared any conflict of interest related to this article.
Financial Disclosure: No financial support was received from any institution or person for our study.

\section{References}

1. Sluder G. Role of the sphenopalatine (Meckel's) ganglion in nasal headaches. N Y State J Med 1908;87:989-990.

2. Headache Classification Subcommittee of the International Headache Society. The International Classification of Headache Disorders: 2nd edition. Cephalalgia 2004;24(Suppl 1):9-160.

3. He W, Zhang Y, Long T, et al. Sphenopalatine neuralgia: an independent neuralgia entity. Pooled analysis of a case series and literature review. Headache 2019;59:358-370.

4. Robbins MS, Robertson CE, Kaplan E, et al. The sphenopalatine ganglion: Anatomy, pathophysiology,and therapeutic targeting in headache. Headache 2016;56:240-258.

5. Oomen KPQ, Van Wijck AJM, Hordijk GJ, De Ru JA. Sluder's neuralgia: a trigeminal autonomic cephalalgia? Cephalalgia 2010;30:360-364.

6. Puig CM, Driscoll CL, Kern EB. Sluder's sphenopalatine ganglion neuralgiatreatment with 88\% phenol. Am J Rhinol 1998;12:113-118.

7. Salar G, Ori C, Iob I, Fiore D. Percutaneous thermocoagulation for sphenopalatine ganglion neuralgia. Acta Neurochir 1987;84:24-28.

8. Headache Classification Committee of the International Headache Society (IHS) The International Classification of Headache Disorders, 3rd edition. Cephalalgia 2018;38:1-211. 